\title{
The response of watercress (Nasturtium officinale) to vacuum impregnation: Effect of an antifreeze protein type I
}

\author{
Rui M.S. Cruz ${ }^{\text {a }}$, Margarida C. Vieira ${ }^{\mathrm{b}}$, Cristina L.M. Silva ${ }^{\mathrm{a}, *}$ \\ ${ }^{a}$ CBQF/Escola Superior de Biotecnologia, Universidade Católica Portuguesa, Rua Dr. António Bernardino de Almeida, 4200-072 Porto, Portugal \\ ${ }^{\mathrm{b}}$ Instituto Superior de Engenharia, Universidade do Algarve, Campus da Penha, 8005-139 Faro, Portugal
}

\begin{abstract}
A B S T R A C T
The setting up of methodologies that reduce the size of ice crystals and reduce or inhibit the recrystallisation phenomena could have an extraordinary significance in the final quality of frozen products and consequently bring out new market opportunities. In this work, the effect of an antifreeze protein type I (AFP-I), by vacuum impregnation (VI), on frozen watercress was studied. The VI pressure, samples' weight, Hunter Lab colour, scanning electron microscopy (SEM), and a wilting test were analysed in this work.

The water intake of watercress samples augmented with vacuum pressure increase. The results also showed that, independently from the vacuum pressure used, the Lab colour parameters between raw and impregnated samples were maintained, showing no significant differences $(P>0.05)$.

A VI of $58 \mathrm{kPa}$, during $5 \mathrm{~min}$, allowed impregnating the AFP-I solution $\left(0.01 \mathrm{mg} \mathrm{ml}^{-1}\right)$ into the watercress samples. The scanning electron microscopy (SEM) analysis showed the AFP-I impregnated frozen samples with better cell wall definition and rounded cell shape with smaller ice crystals compared with the control samples.

The wilting test results corroborated that AFP-I is a valuable additive, since the leaves impregnated with AFP-I showed higher turgidity compared to the control samples.

The present findings will help to better understand the effect of AFP-I, particularly, on frozen watercress microstructure and its importance as valuable food additive in frozen foods and mainly in leafy vegetables.
\end{abstract}

Keywords:

Watercress

Vacuum impregnation

Antifreeze protein type I

Freezing

Ice crystals

Microstructure

\section{Introduction}

The major objective of the freezing process is to extend the shelf-life of foodstuffs. Moreover, frozen products are able to reach the consumer in different parts of the World with a good quality, being this feature one of the most valuable for producers, food retailers and consumers. Nevertheless, if the temperature of the freezing process and the storage conditions for product preservation are not appropriate, problems can arise. In frozen food production, the ice formation should be as fast as possible to minimise structural damages. Also, the temperature fluctuations that may occur during distribution and storage should be minimal, since they can lead to product deterioration and reduce drastically its quality and consequently its commercial value.

The ice formation and recrystallisation phenomena, due to temperatures fluctuations along the cold chain, induce changes, not only in the size and number of ice crystals, but also in their shape

\footnotetext{
* Corresponding author. Tel.: +35122 5580058; fax: +351225090351.

E-mail addresses: rcruz@ualg.pt (R.M.S. Cruz), mvieira@ualg.pt (M.C. Vieira), clsilva@esb.ucp.pt (C.L.M. Silva).
}

and orientation. Recrystallisation corresponds to water migration as a result of local water motions allowing molecular diffusion from one ice crystal to another, more often without change in ice content (Blond and Le Meste, 2004).

The development of innovative and more efficient pretreatments in the freezing process are always in research in order to achieve better food materials, and consequently, higher quality frozen products, satisfying the consumer demands and market requirements.

Setting up methodologies that could reduce the size of ice crystals and reduce or inhibit the recrystallisation phenomenon could have an extraordinary significance in the product final quality and consequently bring out new market opportunities.

Antifreeze proteins (AFPs) or thermal hysteresis proteins (THPs) are able to depress the freezing point of aqueous solutions below the melting point, inhibit ice recrystallisation, and suppress or modify ice crystal growth. The difference between the freezing and the melting point is termed thermal hysteresis. AFPs are found in a large number of organisms, such as fish, bacteria, insects and plants (Yang and Sharp, 2004). These proteins help to protect these organisms in very cold environments by lowering the temperature 
at which ice crystals grow and changing the size and shape of the ice crystals (Atıcı and Nalbantoğlu, 2003; Baardsnes et al., 1999; Banasiak, 2006; Breton et al., 2000; Carpenter and Hansen, 1992; Chapsky and Rubinsky, 1997; Deng and Laursen, 1998; Evans and Fletcher 2001, 2004; Feeney and Yeh, 1998; Fletcher et al., 2001; Gómez and Sjöholm, 2004; Graether et al., 2001; Grandum et al., 1999; Griffith and Ewart, 1995; Griffith et al., 2005; Jarząbek et al., 2009; Kristiansen and Zachariassen, 2005; Kuiper et al., 2003; Li and Sun, 2002; Lu et al., 2002; Robles et al., 2007; Scotter et al., 2006; Smallwood et al., 1999; Strom et al., 2005; Tomczak et al., 2003; Wathen and Jia, 2005; Wu et al., 2001; Yang and Sharp, 2004; Yu and Griffith, 1999; Zhang et al., 2008).

It is thought that AFPs inhibit the development and recrystallisation of intercellular ice by adsorbing onto the surface of ice crystals via van der Waals interactions and/or hydrogen bonds (Yeh et al., 2000). The basis for adsorption specificity lies in a hydrogen-bonding match between groups on the ice-binding site of the AFP and oxygen atoms on the ice lattice. In the winter flounder $\alpha$-helical AFP type I, the regularly spaced hydrophilic threonines (Thr) have been suggested to be the principal ice binding residues (Deluca et al., 1998; DeVries and Lin, 1977; Sicheri and Yang, 1995; Wen and Laursen, 1992). On the other hand, other studies (Chao et al., 1997; Haymet et al., 1998, 1999; Zhang and Laursen, 1998) in which the AFP-I hydrophilic amino acids were replaced with hydrophobic ones, showed that hydrogen bonding is not necessary for the antifreeze effect. Others authors (Davies et al., 2002; Sonnichsen et al., 1996; Yang et al., 1998) reported that the binding mechanism is principally due to the entropic effects of docking a relatively hydrophobic, flat protein surface to ice, as well as van der Waals contacts and the formation of some hydrogen bonds. Wierzbicki et al. (2007) proposed that the AFPs interactions with the ice-water interfacial region "poisons" it and thus stops the ice from growth, and do not bind to ice, but accumulate at the ice-water interface. Therefore, the AFPs ice-binding mechanism details are not yet well established and more studies are still required (Ewart et al., 1999; Wathen and Jia, 2005).

AFPs application in frozen foods may inhibit recrystallisation during freezing, storage, transport and thawing, thus preserving food texture by reducing cellular damage and, by reducing drip also minimise the loss of nutrients (Griffith and Ewart, 1995).

The application of antifreeze proteins in food are reported in the literature. Boonsupthip and Lee (2003) showed the ability of antifreeze proteins to preserve gel-forming functionality of food muscle proteins in frozen conditions. They also conclude that AFP still provides better protection than a conventional cryoprotectant sucrose-sorbitol mixture. Other studies concerning antifreeze proteins have been reported, in frozen meat (Payne et al., 1994; Payne and Young, 1995) and ice cream (Regand and Goff, 2006). Moreover, Khanna and Daggard (2006) showed that the antifreeze proteins can be effective even at low concentrations such as $0.6 \mu \mathrm{g} \mathrm{ml}^{-1}$. Holmberg et al. (2001) also reported antifreeze activity in applications with very low concentrations of AFPs.

Wang et al. (2008) reported that in order to transfer antifreeze protection to a plant, it is crucial to introduce AFPs into the apop- last space to confer an optimal antifreeze effect. This phenomenon occurs since ice forms preferentially in the apoplast where the solute concentration is the lowest. Furthermore, the cellular dehydration and disruption of cell integrity occurs since intracellular water is lost and extracellular ice grows.

Nevertheless, very few studies were found reporting the effect of antifreeze proteins in vegetables (Cutler et al., 1989), and none at all in watercress.

Vacuum impregnation (VI) is a useful process that allows the introduction of valuable additives directly into foodstuffs throughout its pores, protecting natural tissue composition, thus improving texture quality and lowering drip loss, and, in some cases, reduces the need for heat treatment, preserving the product characteristics and heat labile elements. VI, as a pre-treatment step, has been widely used in processes such as freezing, drying and canning, due to its ability in quality improvement (Bolin and Huxsoll, 1993).

In this process (VI), the penetration of external liquid is caused by the combined effect of capillary action and a pressure gradient (i.e., the hydrodynamic mechanism, HDM) (Fito, 1994; Fito and Pastor, 1994). After product immersion in a closed tank containing the liquid phase, VI is carried out in a two steps procedure: first, the vacuum pressure $\left(p_{1}\right)$ is imposed on the system for a short time $\left(t_{1}\right)$, promoting the expansion and outflow of internal gas in the product (the product pore native liquid is released due to the internal gas outflow); second, the atmospheric pressure $\left(p_{2}\right)$ is restored for a certain time (usually $t_{2}=t_{1}$ ) with compression leading to a great reduction in the pores' remaining gas, and subsequent influx of the external liquid into the porous structure (Fito et al., 2001; Gras et al., 2002, 2003).

Fruits and vegetables are suitable for developing high quality vacuum impregnated products, since their porous structure, containing a gas or liquid phase, is susceptible for impregnation with an external solution (Zhao and Xie, 2004).

In view of the fact that there are only a few studies on the AFPs applications in foodstuffs, the objectives of this work were to optimise the VI process in order to mechanically introduce an AFP-I on watercress and test its benefits on the quality of this frozen leafy vegetable microstructure and texture.

\section{Materials and methods}

\section{Raw material}

Raw watercress (Nasturtium officinale) was kindly supplied from a local producer. The leaves were selected $(\mathrm{dia}=1.4 \mathrm{~cm})$, washed thoroughly and analyzed within $24 \mathrm{~h}$.

\section{Vacuum impregnation experiments}

The vacuum impregnation experiments were run in order to select the vacuum pressure value that could guarantee AFP-I solution influx with uniform distribution, and on the other hand preserve watercress initial characteristics.

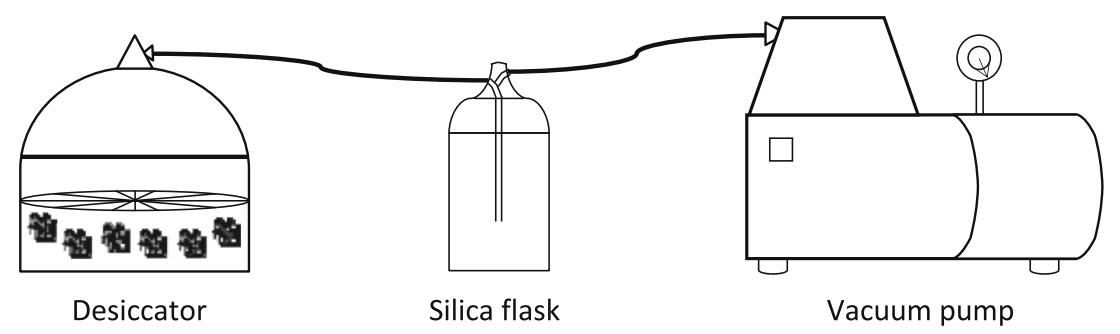

Fig. 1. Vacuum impregnation apparatus. 


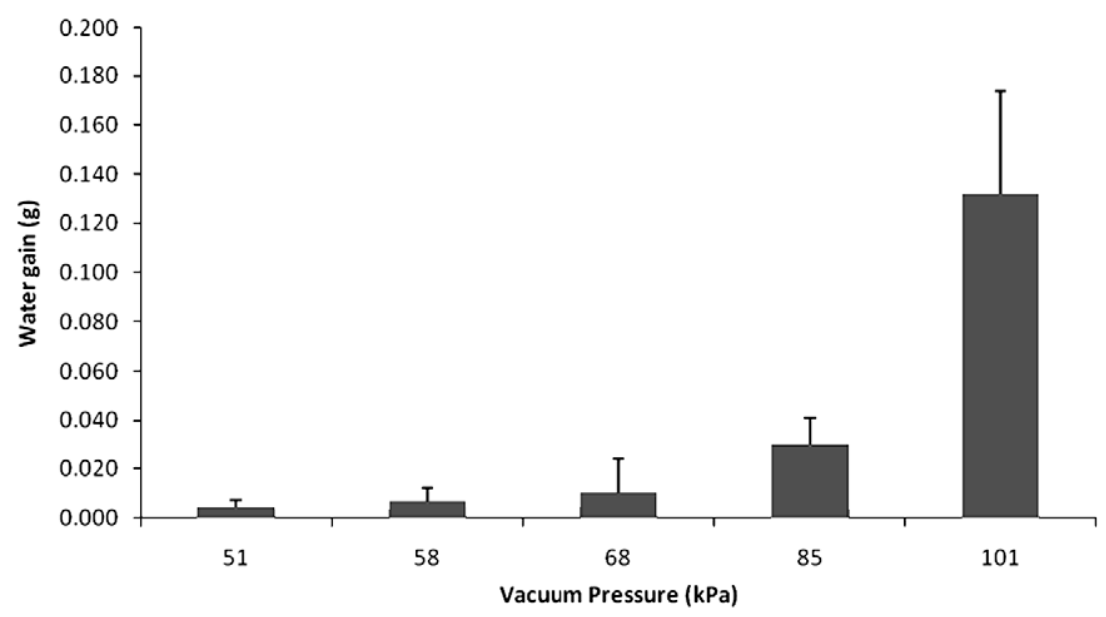

Fig. 2. Effect of vacuum impregnation on watercress water intake, in the vacuum pressure range of $51-101 \mathrm{kPa}$ : Bars represent mean \pm standard deviation.
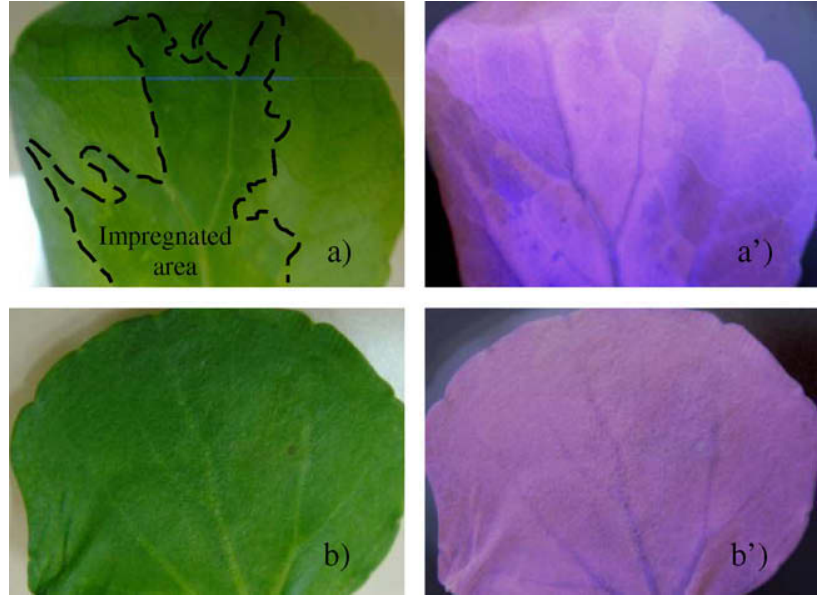

Fig. 3. Effect of vacuum impregnation on watercress water distribution. (a) Impregnated watercress leave at $51 \mathrm{kPa}$; (b) Impregnated watercress leave at $58 \mathrm{kPa}$. ( $\mathrm{a}^{\prime}$ and $\mathrm{b}^{\prime}$ ) represent inverted colour leaves.
The vacuum pressure was firstly tested in order to guarantee minimum water entrance with uniform distribution. The watercress leaves were vacuum impregnated at $20^{\circ} \mathrm{C}$ with ultrapure water at 51, 58, 68, 85 and $101 \mathrm{kPa}$. Each group was treated during $5 \mathrm{~min}$, and the same time was applied after the atmosphere pressure was restored. The vacuum impregnation system was composed by a vacuum pump (Marvac E-L-2, Concord, USA), a vacuum glass desiccator ( $90 \mathrm{~mm}$ dia, Wheaton, USA), a silica flask and a high density polyethylene net in order to maintain the leaves submersed (Fig. 1).

After vacuum pressure selection, the leaves were vacuum impregnated with a winter flounder AFP-I (A/F Protein, Waltham, USA) solution ( $1 \mathrm{mg}$ AFP-I $100 \mathrm{ml}^{-1}$ ultra pure water). Other group of watercress leaves was vacuum impregnated with ultra pure water (control). The experiments were run in six replicates with six watercress leaves each.

\section{Samples` weight determination}

After vacuum treatment superficial water was removed, and each group was weighed in an analytical balance (Shimadzu Aux
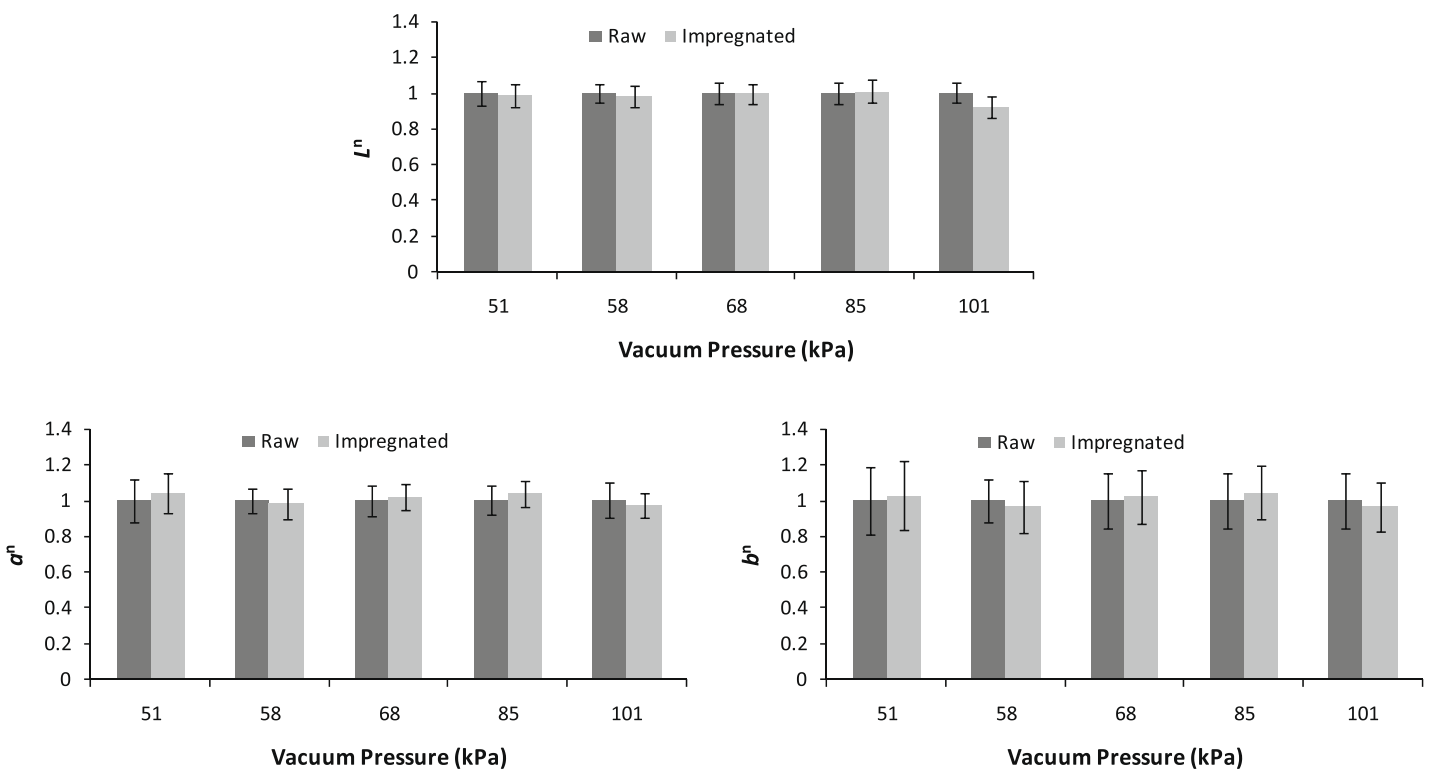

Fig. 4. Effect of vacuum impregnation on watercress colour Lab. parameters, in the vacuum pressure range of 51-101 kPa: Bars represent mean \pm standard deviation. 
Series 220, Kyoto, Japan) in order to test the effect of each vacuum pressure level on watercress water intake.

\section{Colour evaluation}

Colour was evaluated with a tristimulus Dr. Lange Spectro-colour colorimeter (Berlin, Germany) in the Hunter system (Hunter Lab, 2000). The colorimeter $\left(\mathrm{d} / 8^{\circ}\right.$ geometry, illuminant $\mathrm{D} 65,10^{\circ}$ observer) was calibrated against a standard ceramic white tile $(X=84.60, Y=89.46, Z=93.85)$ and a standard ceramic black tile $(X=4.12, Y=4.38, Z=4.71)$. Measurements were taken with six replicates.

To minimise the variability between different raw samples, the individual $L, a$ and $b$ values were normalised $\left({ }^{\mathrm{n}}\right)$, dividing the parameters by the corresponding initial values.

The objective of this methodology was to detect possible differences between the colour of the raw and the impregnated samples.

\section{Microstructure quality evaluation}

After vacuum impregnation treatment and superficial water removal, the leaves were frozen in a vertical freezer at $-80^{\circ} \mathrm{C}(\mathrm{Snij}-$ ders Scientific, Tilburg, Netherlands). Afterwards, based on the method reported by Fonseca et al. (2005), the samples were transversally cut with a surgery thin blade and observed in a scanning electron microscope (SEM) (JEOL JSM-5600 LV, Tokyo, Japan) at low vacuum with an acceleration voltage of $15 \mathrm{kV}$ and a cryochamber set at $-25^{\circ} \mathrm{C}$. The experiments were run with six replicates.

\section{Wilting test}

Based on the method reported by Phoon et al. (2008), raw, AFP-I vacuum impregnated samples and control samples (vacuum impregnated with ultrapure water) were frozen at $-80^{\circ} \mathrm{C}$ (Snijders
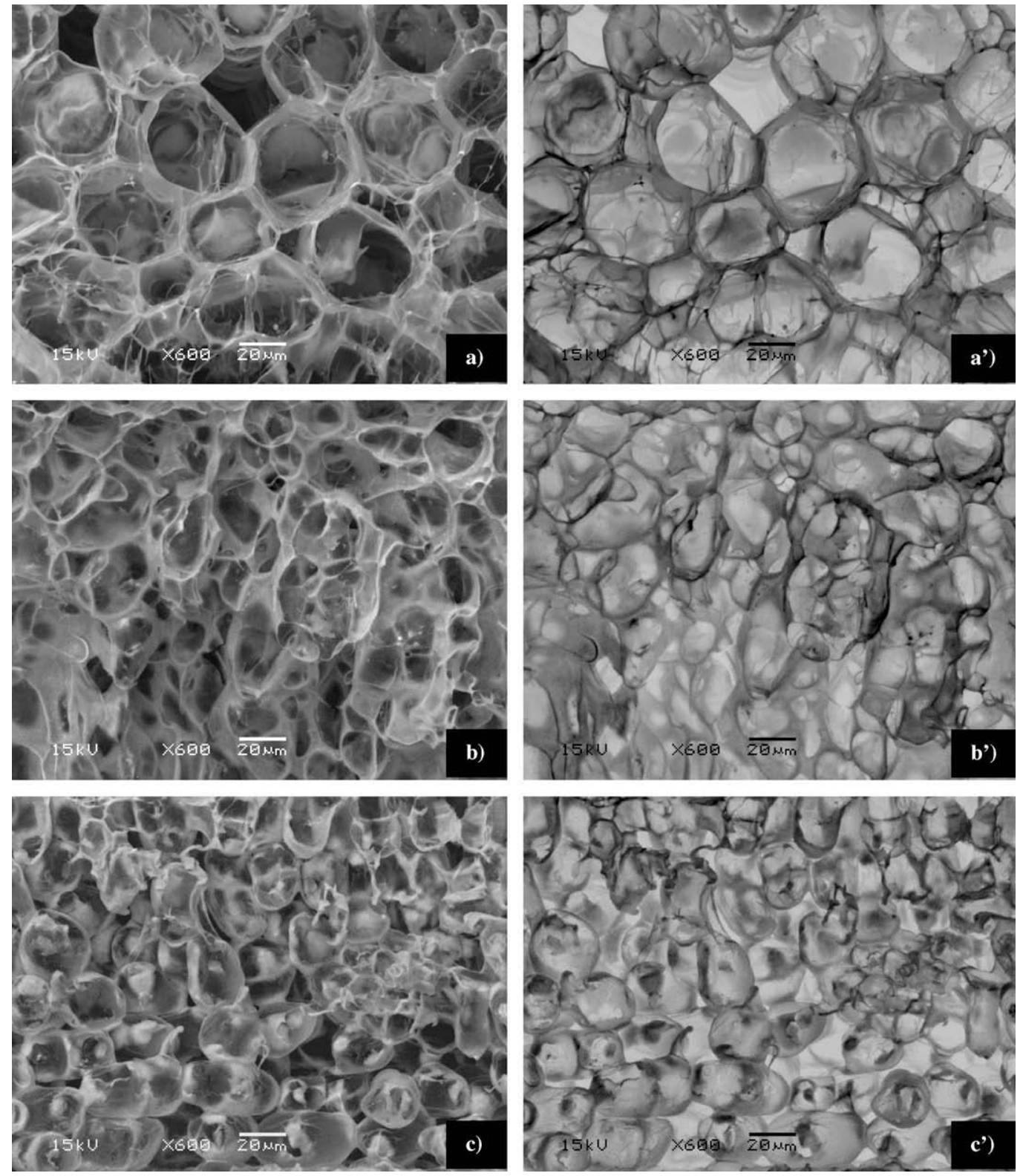

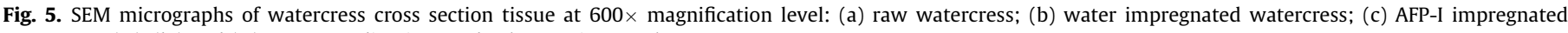
watercress. $\left(a^{\prime}\right),\left(b^{\prime}\right)$ and $\left(c^{\prime}\right)$ Corresponding inverted colours micrographs. 
Scientific, Tilburg, Netherlands). Afterwards, the turgidity was tested by holding the centre of the leaves using a small pincer and observing the bendiness of the samples. The experiments were run with six replicates thawed at room temperature.

\section{Statistical analysis}

The analysis of variance (ANOVA) of the results was carried out to determine if there were significant differences between each vacuum treatment. Calculations were performed using the Microsoft EXCEL 2003 data analysis tool package. Evaluations were based on a significance level of $5 \%$.

\section{Results and discussion}

Watercress samples water intake increased with vacuum pressure values rise (Fig. 2), since the external liquid influx is directly related with vacuum pressure increase. Watercress samples treated at $51 \mathrm{kPa}$ showed some water gain, however after each vacuum treatment and by mere eye observation it was noticed that the samples were not totally impregnated, being the water gain randomly distributed (Fig. 3a and $a^{\prime}$ ). Moreover, fresh appearance was showed in various watercress areas. Vacuum treatment at $58 \mathrm{kPa}$ was selected since it gathered the imposed conditions, assuring water influx with uniform distribution (Fig. $3 \mathrm{~b}$ and $\mathrm{b}^{\prime}$ ). Thus, higher vacuum pressure treatments that could lead to cellular disruption were not assessed.

The watercress colour was also evaluated in order to detect differences between vacuum treated and raw samples. The results showed that, independently from the vacuum pressure used, the Lab colour parameters were maintained (Fig. 4), showing no significant differences $(P>0.05)$.

In what concerns the microstructure analysis, the control sample showed the parenchyma cells covered with an ice layer and with poor cell wall definition (Fig. $5 b$ and $b^{\prime}$ ). The watercress samples, impregnated with AFP-I, showed better cell wall definition and rounded cell shape with smaller ice crystals (Fig. $5 c$ and $c^{\prime}$ ). These results showed that the AFP-I interfered in the ice crystals formed during water freezing. The formation of small ice crystals was probably due to the hydrogen bonds between water molecules and AFP-I, hence disturbing the normal ice crystals net generation. According to Yang et al. (1988) the AFP-I threonine residues are responsible to bind to the oxygen atoms. The AFP-I interferes in the ice crystals structure and reduces the size of the ice crystal net, since oxygen and hydrogen bonds are in less number.

The regularly-spaced threonine residues along one face of this protein are thought to play an important role in AFP-ice binding, particularly because their spacing, once suitably aligned, matches the oxygen atom spacing of the presumed AFP-binding ice plane. Moreover, threonine residues are hydrophilic, so the type I AFP face containing these residues appears to be a natural choice for the icebinding surface of this protein, particularly since alanine residues, which make up the majority of the rest of the protein surface, are hydrophobic (water-avoiding) (Wathen and Jia, 2005). Nevertheless, as previously reported, this adsorption mechanism is not yet well established.

The microstructure of the samples with AFP-I also presented the parenchyma cells more similar to the raw samples microstructure (Fig. $5 a$ and $a^{\prime}$ ). Thus, these results establish, once more, the capa-
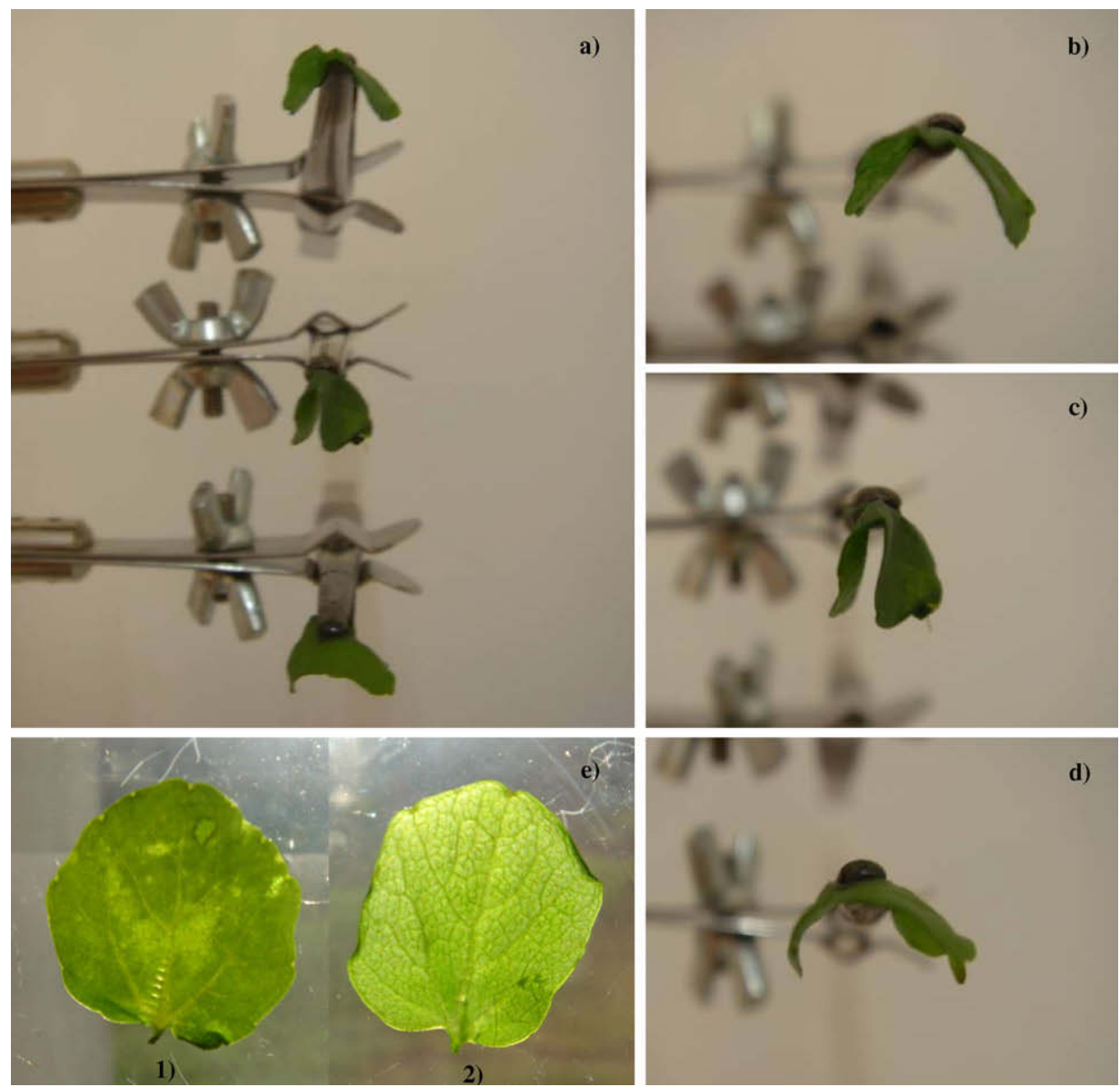

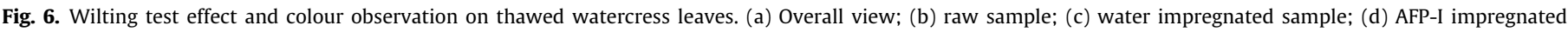
sample; (e) 1- raw watercress, 2- AFP-I impregnated watercress. 
bility of AFP-I generating small ice crystals, and in further ice crystals size regulation, regarding temperature fluctuations. Previous studies on frozen meat (Payne et al., 1994; Payne and Young, 1995) also reported the formation of small ice crystals due to the presence of AFPs. Also, according to Hansen and Carpenter (1993), solutions of hydroxyethyl starch with AFPs showed smaller ice crystals at $-10^{\circ} \mathrm{C}$ and $30 \mathrm{~min}$.

The wilting test results corroborate the AFPs use as a valuable additive, since the leaves impregnated with AFP-I showed higher turgidity compared to the control samples (Fig. $6 \mathrm{c}$ and d), which simply collapsed. The lack of turgidity showed by the control is related to the formation of ice crystals of larger dimensions that occurred during the freezing process and consequently inflicted higher cellular disruption and drip loss after thawing. Moreover, the AFP-I impregnated samples and raw samples showed similar turgidity and higher mechanical strength (Fig. 6a, b and d). This turgidity and better watercress texture was due to the formation of small ice crystals resulting in a higher water-holding capacity and cellular integrity. These outcomes may also result in a higher nutrient content retention. In another research study (Payne and Wilson, 1994), frozen and thawed Antarctic cod, naturally containing AFPs, also revealed a lower drip loss resulting in a better flesh quality. According to Cutler et al. (1989), leaves of potato, canola, and Arabidopsis thaliana plants vacuum-infiltrated with AFPs and exposed to freezing conditions were found to be more cold hardy than the controls (water infiltrated). Also, Ralfs et al. (2003) reported that carrot tissue infiltrated with AFPs, had a significantly greater stiffness and mechanical strength than the tissue infiltrated with ultrapure water.

In this study, the AFP-I watercress thawed samples also presented a more uniform green colour compared with the raw thawed samples (Fig. 6e-1 and e-2), confirming this treatment as a suitable process, in colour improvement, before the freezing operation.

\section{Conclusion}

This study revealed that AFP-I application, as a food additive, can have a major impact in frozen watercress quality since it reduced the size of the ice crystals, avoiding less damage to the microstructure, and thus improving its texture after thawing.

Also the applied vacuum impregnation methodology allowed introducing successfully the AFPs into the watercress apoplast space, revealing to be an efficient methodology to incorporate valuable compounds in order to increase the quality of the final product.

The present findings help to understand the effect of AFP-I on frozen watercress microstructure and its important role as a valuable food additive, preserving food quality and probably the nutritional value in foods that undergo cold storage.

Introducing this type of proteins in frozen foodstuffs could help, in a near future, to reduce the issues that occur in the freezing process and cold chain due to temperature fluctuations. The frozen products may become more stable since ice crystals will remain smaller and thus preventing further deteriorations.

Although the application of these proteins, from the original source or produced by genetically modified organisms is still a controversial issue, AFPs have not been related with any known toxic effect of fish consumption (Crevel et al., 2000). Moreover, they are already being applied by some major ice cream producers. Thus, further research is mandatory for other type of food products applications in order to demystify its possible safety drawbacks.

\section{Symbol}

$a$

b

Colour co-ordinate, represents red to green

Colour co-ordinate, represents blue to yellow Colour co-ordinate, represents black to white

\section{Acknowledgments}

The author Rui M.S. Cruz gratefully acknowledges his Ph.D. Grant SFRH/BD/9172/2002 to Fundação para a Ciência e a Tecnologia (FCT) from Ministério da Ciência e do Ensino Superior. The authors thank the Vitacress Company for supplying the raw watercress.

\section{References}

Atıcı, Ö., Nalbantoğlu, B., 2003. Antifreeze proteins in higher plants. Phytochemistry $64,1187-1196$

Baardsnes, J., Kondejewski, L.H., Hodges, R.S., Chao, H., Kay, C., Davies, P.L., 1999 New ice-binding face for type I antifreeze protein. Federation of European Biochemical Societies FEBS Letters 463, 87-91.

Banasiak, K., 2006. News. Food Technology 60, 12.

Blond, G., Le Meste, M., 2004. Principles of frozen storage. In: Hui, Y.E., Cornillon, P., Legaretta, I.G., Lim, M.H., Murrell, K.D., Nip, W. (Eds.), Handbook of Frozen Foods. Marcel Dekker, New York (pp. 30).

Bolin, H.R., Huxsoll, C.C., 1993. Partial drying of cut pears to improve freeze-thaw texture. Journal of Food Science 58, 357-360.

Boonsupthip, W., Lee, T., 2003. Application of antifreeze protein for food preservation: effect of type III antifreeze protein for preservation of gelforming of frozen and chilled actomyosin. Journal of Food Science 68, 18041809.

Breton, G., Danyluk, J., Ouellet, F., Sarhan, F., 2000. Biotechnological applications of plant freezing associated proteins. Biotechnology Annual Review 6, 57-99.

Carpenter, J.F., Hansen, T.N., 1992. Antifreeze protein modulates cell survival during cryopreservation: mediation through influence on ice crystal growth. Proceedings of the National Academy of Sciences 89, 8953-8957.

Chao, H., Houston Jr., M.E., Hodges, R.S., Kay, C.M., Sykes, B.D., Loewen, M.C., Davies, P.L., Sönnichsen, F.D., 1997. A diminished role for hydrogen bonds in antifreeze protein binding to ice. Biochemistry 36, 14652-14660.

Chapsky, L., Rubinsky, B., 1997. Kinetics of antifreeze protein-induced ice growth inhibition. Federation of European Biochemical Societies FEBS Letters 412, 241 244.

Crevel, R.W.R., Fedyk, J.K., Spurgeon, M.J., 2000. Antifreeze proteins: characteristics, occurrence and human exposure, review. Journal of Food and Chemical Toxicology 40, 899-903.

Cutler, A.J., Saleem, M., Kendall, E., Gusta, L.V., Georges, F., Fletcher, G.L., 1989 Winter flounder antifreeze protein improves the cold hardiness of plant tissues. Journal of Plant Physiology 135, 351-354.

Davies, P.L., Baardsnes, J., Kuiper, M.J., Walker, V.K., 2002. Structure and function of antifreeze proteins. Philosophical Transactions of the Royal Society B: Biological Sciences 357, 927-935.

DeLuca, C.I., Comley, R., Davies, P.L., 1998. Antifreeze proteins bind independently to ice. Biophysical Journal 74, 1502-1508

Deng, G., Laursen, R.A., 1998. Isolation and characterization of an antifreeze protein from the longhorn sculpin, Myoxocephalus octodecimspinosis. Biochimica et Biophysica Acta 1388, 305-314.

DeVries, A.L., Lin, Y., 1977. Structure of a peptide antifreeze and mechanisms of absorption to ice. Biochimica et Biophysica Acta 495, 380-392.

Evans, R.P., Fletcher, G.L., 2001. Isolation and characterization of type I antifreeze proteins from Atlantic snailfish (Liparis atlanticus) and dusky snailfish (Liparis gibbus). Biochimica et Biophysica Acta 1547, 235-244.

Evans, R.P., Fletcher, G.L., 2004. Isolation and purification of antifreeze proteins from skin tissues of snailfish, cunner and sea raven. Biochimica et Biophysica Acta 1700, 209-217.

Ewart, K.V., Lin, Q., Hew, C.L., 1999. Review: structure, function and evolution of antifreeze proteins. Cellular Molecular Life Sciences 55, 271-283.

Feeney, R.E., Yeh, Y., 1998. Antifreeze proteins: Current status and possible food uses. Trends in Food Science and Technology 9, 102-106.

Fito, P., 1994. Modelling of vacuum osmotic dehydration of food. Journal of Food Engineering 22, 313-328.

Fito, P., Chiralt, A., Betoret, N., Gras, M., Chafer, M., Martinez-Monzo, J., Andres, A., Vidal, D., 2001. Vacuum impregnation and osmotic dehydration in matrix engineering application in functional fresh food development. Journal of Food Engineering 49, 175-183.

Fito, P., Pastor, R., 1994. Non-diffusional mechanisms occurring during vacuum osmotic dehydration. Journal of Food Engineering 21, 513-519.

Fletcher, G.L., Hew, C.L., Davies, P.L., 2001. Antifreeze proteins of teleost fishes Annual Review of Physiology 63, 359-390.

Fonseca, S.C., Silva, C.L., Malcata, F.X., 2005. Microstructural analysis of fresh-cut red bell pepper (Capsicum annuum L.) for postharvest quality optimization. Electronic Journal of Environmental, Agricultural and Food Chemistry 4 (108) $1-1085$.

Gómez, G.F., Sjöholm, I., 2004. Applying biochemical and physiological principles in the industrial freezing of vegetables: a case study on carrots. Trends in Food Science and Technology 15, 39-43.

Graether, S.P., Slupsky, C.M., Davies, P.L., Sykes, B.D., 2001. Structure of type antifreeze protein and mutants in supercooled water. Biophysical Journal 81 1677-1683. 
Grandum, S., Yabe, A., Nakagomi, K., Tanaka, M., Takemura, F., Kobayashi, Y., Frivik, P., 1999. Analysis of ice crystal growth for a crystal surface containing adsorbed antifreeze proteins. Journal of Crystal Growth 205, 382-390.

Gras, M., Vidal-Brotóns, D., Betoret, N., Chiralt, A., Fito, P., 2002. The response of some vegetables to vacuum impregnation. Innovative Food Science and Emerging Technologies 3, 263-269.

Gras, M.L., Vidal, D., Betoret, N., Chiralt, A., Fito, P., 2003. Calcium fortification of vegetables by vacuum impregnation interactions with cellular matrix. Journal of Food Engineering 56, 279-284.

Griffith, M., Ewart, K.V., 1995. Antifreeze proteins and their potential use in frozen foods. Biotechnology Advances 13, 375-402.

Griffith, M., Lumb, C., Wiseman, S.B., Wisniewski, M., Johnson, R.W., Marangoni, A.G., 2005. Antifreeze proteins modify the freezing process in planta. Plant Physiology 138, 330-340.

Hansen, T.N., Carpenter, J.F., 1993. Calorimetric determination of inhibition of ice crystal growth by antifreeze protein in hydroxyethyl starch solutions. Biophysical Journal 64, 1843-1850.

Haymet, A.D.J., Ward, L.G., Harding, M.M., 1999. Winter flounder "antifreeze" proteins: synthesis and ice growth inhibition of analogues that probe the relative importance of hydrophobic and hydrogen-bonding interactions. Journal of the American Chemical Society 121, 941-948.

Haymet, A.D.J., Ward, L.G., Harding, M.M., Knight, C.A., 1998. Valine substituted winter flounder "antifreeze": preservation of ice growth hysteresis. Federation of European Biochemical Societies FEBS Letters 430, 301-306.

Holmberg, N., Farrés, J., Bailey, J.E., Kallio, P.T., 2001. Targeted expression of a synthetic codon optimized gene, encoding the spruce budworm antifreeze protein, leads to accumulation of antifreeze activity in the apoplasts of transgenic tobacco. Gene 275, 115-124.

Hunter Lab., 2000. Applications notes 12 (5), 1-8.

Jarzabek, M., Pukacki, P.M., Nuc, K., 2009. Cold-regulated proteins with potent antifreeze and cryoprotective activities in spruces (Picea spp.). Cryobiology. doi:10.1016/j.cryobiol.2009.01.007.

Khanna, H.K., Daggard, G.E., 2006. Targeted expression of redesigned and codon optimised synthetic gene leads to recrystallisation inhibition and reduced electrolyte leakage in spring wheat at sub-zero temperatures. Plant Cell Reports $25,1336-1346$.

Kristiansen, E., Zachariassen, K.E., 2005. The mechanism by which fish antifreeze proteins cause thermal hysteresis. Cryobiology 51, 262-280.

Kuiper, M.J., Lankin, C., Gauthier, S.Y., Walker, V.K., Davies, P.L., 2003. Purification of antifreeze proteins by adsorption to ice. Biochemical and Biophysical Research Communications 300, 645-648.

Li, B., Sun, D., 2002. Novel methods for rapid freezing and thawing of foods - a review. Journal of Food Engineering 54, 175-182.

Lu, M., Wang, B., Li, Zh., Fei, Y., Wei, L., Gao, Sh., 2002. Differential scanning calorimetric and circular dichroistic studies on plant antifreeze proteins. Journal of Thermal Analysis and Calorimetry 67, 689-698.

Payne, S.R., Sandford, D., Harris, A., Young, O.A., 1994. The effects of antifreeze proteins on chilled and frozen meat. Meat Science 37, 429-438.

Payne, S.R., Wilson, P.W., 1994. Comparison of the freeze-thaw characteristics of antartic cod (Dissostichus mawsoni) and black cod (Paranotothenia augustata) possible effects of antifreeze glycoproteins. Journal of Muscle Foods 5, 233-244.

Payne, S.R., Young, O.A., 1995. Effect of pre-slaughter administration of antifreeze proteins on frozen meat quality. Meat Science 41, 147-155.

Phoon, P.Y., Galindo, F.G., Vicente, A., Dejmek, P., 2008. Pulsed electric field in combination with vacuum impregnation with trehalose improves the freezing tolerance of spinach leaves. Journal of Food Engineering 88, 144-148.

Ralfs, J.D., Sidebottom, C.M., Ormerod, A.P., 2003. Antifreeze proteins in 444 vegetables. World intellectual property organization, patent WO 03/055320 A1. pp. 1-8.

Regand, A., Goff, H.D., 2006. Ice recrystallization inhibition in ice cream as affected by ice structuring proteins from winter wheat grass. Journal of Dairy Science 89 $49-57$.
Robles, V., Barbosa, V., Herráez, M.P., Martínez-Páramo, S., Cancela, M.L., 2007. The antifreeze protein type I (AFP I) increases seabream (Sparus aurata) embryos tolerance to low temperatures. Theriogenology 68, 284-289.

Scotter, A.J., Marshall, C.B., Graham, L.A., Gilbert, J.A., Garnham, C.P., Davies, P.L., 2006. The basis for hyperactivity of antifreeze proteins. Cryobiology 53, 229239.

Sicheri, F., Yang, D.S.C., 1995. Ice-binding structure and mechanism of an antifreeze protein from winter flounder. Nature 375, 427-431.

Smallwood, M., Worrall, D., Byass, L., Elias, L., Ashford, D., Doucet, C.J., Holt, C. Telford, J., Lillford, P., Bowles, D.J., 1999. Isolation and characterization of a novel antifreeze protein from carrot (Daucus carota). Biochemical Journal 340, 385-391.

Sonnichsen, F.D., DeLuca, C.I., Davies, P.L., Sykes, B.D., 1996. Refined solution structure of type III antifreeze protein: hydrophobic groups may be involved in the energetics of the protein-ice interaction. Structure 4,1325-1337.

Strom, C.S., Liu, X.Y., Jia, Z., 2005. Ice surface reconstruction as antifreeze proteininduced morphological modification mechanism. Journal of the American Chemical Society $127,428-440$.

Tomczak, M.M., Marshall, C.B., Gilbert, J.A., Davies, P.L, 2003. A facile method for determining ice recrystallization inhibition by antifreeze proteins. Biochemical and Biophysical Research Communications 311, 1041-1046.

Wang, Y., Qiu, L., Dai, C., Wang, J., Luo, J., Zhang, F., Ma, J., 2008. Expression of insect (Microdera puntipennis dzungarica) antifreeze protein MpAFP149 confers the cold tolerance to transgenic tobacco. Plant Cell Reports 27, 1349-1358.

Wathen, B., Jia, Z., 2005. Controlling the freezing process with antifreeze proteins. In: Sun, D. (Ed.), Emerging Technologies for Food Processing. Elsevier, London (pp. 653-674)

Wen, D., Laursen, R.A., 1992. Structure-function relationships in an antifreeze polypeptide: the role of neutral, polar amino acids. Journal of Biological Chemistry 267, 14102-14108.

Wierzbicki, A., Dalal, P., Cheatham, T.E., Knickelbein, J.E., Haymet, A.D.J., Madura, J.D., 2007. Antifreeze proteins at the ice/water interface: three calculated discriminating properties for orientation of type I proteins. Biophysical Journal 93, 1442-1451.

Wu, Y., Banoub, J., Goddard, S.V., Kao, M.H., Fletcher, G.L., 2001. Antifreeze glycoproteins: relationship between molecular weight, thermal hysteresis and the inhibition of leakage from liposomes during thermotropic phase transition. Comparative Biochemistry and Physiology Part B 128, 265-273.

Yang, D.S., Hon, W.C., Bubanko, S., Xue, Y., Seetharaman, J., Hew, C.L., Sicheri, F., 1998. Identification of the ice-binding surface on a type III antifreeze protein with a "flatness function" algorithm. Biophysical Journal 74, 2142-2151.

Yang, D.S.C., Sax, M., Chakrabartty, A., Hew, C.L., 1988. Crystal structure of an antifreeze polypeptide and its mechanistic implications. Nature 333, 232-237.

Yang, C., Sharp, K.A., 2004. The mechanism of the type III antifreeze protein action: a computational study. Biophysical Chemistry 109, 137-148.

Yeh, S., Moffatt, B.A., Griffith, M., Xiong, F., Yang, D.S.C., Wiseman, S.B., Sarhan, F., Danyluk, J., Xue, Y.Q., Hew, C.L., Doherty-Kirby, A., Lajoie, G., 2000. Chitinase genes responsive to cold encode antifreeze proteins in winter cereals. Plant Physiology 124, 1251-1263.

Yu, X., Griffith, M., 1999. Antifreeze proteins in winter rye leaves form oligomeric complexes. Plant Physiology 119, 1361-1369.

Zhang, W., Laursen, R.A., 1998. Structure-function relationship in type I antifreeze polypeptide. Journal of Biological Chemistry 273, 34806-34812.

Zhang, C., Zhang, H., Wang, L., Guo, X., 2008. Effect of carrot (Daucus carota) antifreeze proteins on texture properties of frozen dough and volatile compounds of crumb. Lebensmittel-Wissenshaft und Technologie 41, 10291036.

Zhao, Y., Xie, J., 2004. Practical applications of vacuum impregnation in fruit and vegetable processing. Trends in Food Science and Technology 15, 434-451. 